\title{
Fluorinated Polyimides Based on 3,3-Bis[4-(4-amino-2-trifluoromethylphenoxy)phenyl]phthalide
}

\author{
Chin-Ping YANG, ${ }^{\dagger}$ Hsun-Ching CHIANG, and Yu-Yang SU \\ Department of Chemical Engineering, Tatung University, 40 Chungshan North Road, Section 3, Taipei 104, Taiwan
}

(Received August 4, 2004; Accepted September 14, 2004; Published December 15, 2004)

\begin{abstract}
A novel fluorinated diamine monomer, 3,3-bis[4-(4-amino-2-trifluoromethylphenoxy)phenyl]phthalide (II), was prepared through the nucleophilic substitution reaction of 2-chloro-5-nitrobenzotrifluoride with phenolphthalein in the presence of potassium carbonate to yield the intermediate dinitro compound $\mathbf{I}$, followed by catalytic reduction with hydrazine and $\mathrm{Pd} / \mathrm{C}$. Polyimides $\mathbf{V}$ were synthesized from diamine II and various aromatic dianhydrides III $_{\mathrm{a}-\mathrm{f}}$ via thermal or chemical imidization of poly(amic acid)s. These polymers had inherent viscosities ranging from 0.63 to $0.95 \mathrm{dL} / \mathrm{g}$ and were soluble in a variety of organic solvents. $\mathbf{V}_{\mathrm{a}-\mathrm{f}}$ films had tensile strengths of 105-125 MPa, elongations to break of $9-12 \%$, and initial modulus of $2.35-2.65 \mathrm{GPa}$. The glass transition temperatures of these polymers were recorded $259-320^{\circ} \mathrm{C}$, and no significant weight loss was observed below a temperature of $500{ }^{\circ} \mathrm{C}$ in nitrogen or in air. Compared with nonfluorinated homologues VI, $\mathbf{V}$ showed better solubility and lower color intensity, dielectric constant (2.70-3.11 at $1 \mathrm{MHz})$, and moisture absorption (0.12-0.27 wt \%). In particular, $\mathbf{V}_{\mathrm{c}-\mathrm{f}}$ afforded lightly colored films, which had cutoff wavelengths lower than $380 \mathrm{~nm}$ and yellowness index ( $b^{*}$ values) ranging from 9 to 25 . On comparing thermal imidized polymers with chemical imidized ones, films $\mathbf{V}_{\mathrm{a}-\mathrm{f}}(\mathbf{C})$ showed a lower color intensity than $\mathbf{V}_{\mathrm{a}-\mathrm{f}}(\mathbf{H})$ did. [DOI 10.1295/polymj.36.979]

KEY WORDS Organosoluble / Light-Colored / Fluorinated / Polyimides / 3,3-Bis[4-(4-amino-2trifluoromethylphenoxy)phenyl]phthalide /
\end{abstract}

Aromatic polyimides are well known as polymer materials of high performance for their excellent thermal stabilities and balanced mechanical and electric properties. ${ }^{1-6}$ They are mainly used in the aerospace and electronics industries in the form of films and moldings. Moreover, optical transparency of polyimide films is of special importance in some applications such as flexible solar radiation protectors, ${ }^{7}$ orientation films in liquid crystal display devices ${ }^{8}$ optical waveguides for communication interconnects, ${ }^{9}$ and optical half-waveplates for planar lightwave circuits. ${ }^{10}$ However, the wholly aromatic polyimides strongly absorb in the visible region of their UV-vis spectra and are pale yellow or deep reddish yellow because of their highly conjugated aromatic structures and/or the intermolecular charge-transfer complex (CTC) formation; besides, they are difficult to process because of high softening temperatures and limited solubility in commercially available solvents.

A low dielectric constant is one of the most attractive properties of polyimide materials for electronic applications. ${ }^{11}$ One of the most effective methods to decrease the dielectric constant is to introduce fluorine atoms into polyimide materials. ${ }^{12}$ As is well-known, the fluorine atom has unique characteristics, such as high electronegativity and low electric polarity. These properties give fluorinated polymers attractive features such as water and oil repellence, low permittiv- ity, low refractive indices, resistance to wear and abrasion, and thermal and chemical stability. Fluorination is also known to enhance the solubility and optical transparency and to lower moisture absorption of polyimides. ${ }^{13-15}$

In our previous papers, ${ }^{16,17}$ we have successfully used the alylene ether-containing cardo diamines of 3,3-bis[4-(4-aminophenoxy)phenyl]phthalide $\left(\mathbf{I I}^{\prime}\right)$, derived from phenolphthalein and $p$-chloronitrobenzene, for the preparation of aromatic polyimides. We have found that polymers containing cyclic side cardo group were enhance solubility while maintaining their thermal stability. In this study, a high-purity $\mathrm{CF}_{3}$-containing diamine, 3,3-bis[4-(4-amino-2-trifluoromethylphenoxy)phenyl]phthalide (II), was synthesized by modificatory method and subsequently polycondensed with various commercially available aromatic dianhydrides to produce a series of fluorinated polyimides $\left(\mathbf{V}_{\mathrm{a}-\mathrm{f}}\right)$. These polymers were subjected to solubility, moisture absorption, and thermal, optical, and dielectric property measurements and compared to analogous polyimides $\left(\mathbf{V I}_{\mathrm{a}-\mathrm{f}}\right)$ prepared from a nonfluorinated diamine monomer $\mathbf{I I}^{\prime}$.

\section{EXPERIMENTAL}

\section{Materials}

Phenolphthalein (Acros) and 2-chloro-5-nitroben-

${ }^{\dagger}$ To whom correspondence should be addressed (E-mail: cpyang@ttu.edu.tw). 
zotrifluoride (Acros) were used as received. Pyromellitic dianhydride (PMDA or III $\mathbf{a}_{\mathrm{a}}$; Lancaster), 3, 3', 4, $4^{\prime}$ benzophenonetetracarboxylic dianhydride (BTDA or III $_{\mathrm{b}}$; Acros), and 4,4'-oxydiphthalic dianhydride (ODPA or III $_{\mathrm{e}}$; Chriskev) were recrystallized from acetic anhydride before use. 3,3',4,4'-Biphenyltetracarboxylic dianhydride (BPDA or III $_{\mathrm{c}}$; Chriskev), diphenylsulfone-3,3',4,4'-tetracarboxylic dianhydride (DSDA or III $_{\mathrm{d}}$; New Japan Chemical Co.) and 2,2bis(3,4-dicarboxyphenyl)hexafluoropropane dianhydride (6FDA or $\mathbf{I I I}_{\mathrm{f}}$; Chriskev) were purified by sublimation. Others solvents included $N$-methyl-2pyrrolidone (NMP; Fluka), $\mathrm{N}, \mathrm{N}$-dimethylacetamide (DMAc; Fluka), $N, N$-dimethylformamide (DMF; Fluka), and pyridine (Py; Wako).

\section{Synthesis of Monomer}

3,3-Bis [4-(4-nitro-2-trifluoromethylphenoxy)phenyl]phthalide $(\boldsymbol{I})$. Phenolphthalein $(10.28 \mathrm{~g}, 0.0323$ $\mathrm{mol}$ ) and 2-chloro-5-nitrobenzotrifluoride (14.62 g, $0.0648 \mathrm{~mol}$ ) were first dissolved in $25 \mathrm{~mL}$ of DMAc in a $100-\mathrm{mL}$ flask with stirring. After the mixture was completely dissolved, potassium carbonate $(6.7 \mathrm{~g}$, $0.048 \mathrm{~mol}$ ) was added to it in one portion, and the mixture was heated at $110^{\circ} \mathrm{C}$ for $12 \mathrm{~h}$. The obtained mixture was poured into $100 \mathrm{~mL}$ of methanol/water (volume ratio 2/1) to give a pale-yellow solid, which was collected, washed with water, and dried under vacuum $(23 \mathrm{~g})$. The crude product was purified from glacial acetic acid, followed by washing with hot water to give white powder ( $21 \mathrm{~g}, 93 \%)$.

mp: $145-146^{\circ} \mathrm{C}$ by differential scanning calorimetry (DSC) at a scan rate of $5^{\circ} \mathrm{C} / \mathrm{min}$. IR $(\mathrm{KBr})$ : 1530, 1350 ( $-\mathrm{NO}_{2}$ stretch), 1286, 1180, 1145, 1118 $\mathrm{cm}^{-1}$ (C-F and C-O stretch). ${ }^{1} \mathrm{H}$ NMR (DMSO- $d_{6}$, $\delta): 8.52\left(\mathrm{~d}, J=2.7 \mathrm{~Hz}, 2 \mathrm{H}, \mathrm{H}_{\mathrm{a}}\right), 8.45(\mathrm{dd}, J=9.2$, $\left.2.75 \mathrm{~Hz}, 2 \mathrm{H}, \mathrm{H}_{\mathrm{b}}\right), 8.01(\mathrm{t}, J=7.95,7.8 \mathrm{~Hz}, 2 \mathrm{H}$, $\left.\mathrm{H}_{\mathrm{f}, \mathrm{i}}\right), 7.94\left(\mathrm{t}, J=7.54,7.33 \mathrm{~Hz}, 1 \mathrm{H}, \mathrm{H}_{\mathrm{g}}\right), 7.75(\mathrm{t}, J=$ $\left.7.53,7.45 \mathrm{~Hz}, 1 \mathrm{H}, \mathrm{H}_{\mathrm{h}}\right), 7.54\left(\mathrm{~d}, J=9.4 \mathrm{~Hz}, 4 \mathrm{H}, \mathrm{H}_{\mathrm{e}}\right)$, $7.31\left(\mathrm{~d}, J=9.2 \mathrm{~Hz}, 4 \mathrm{H}, \mathrm{H}_{\mathrm{d}}\right), 7.21(\mathrm{~d}, J=9.2 \mathrm{~Hz}, 2 \mathrm{H}$, $\mathrm{H}_{\mathrm{c}}$ ). ${ }^{13} \mathrm{C}$ NMR (DMSO- $\left.d_{6}, \delta\right): 168.5\left(\mathrm{C}^{17}\right), 159.5$ $\left(\mathrm{C}^{4}\right), 154.2\left(\mathrm{C}^{7}\right), 151.0\left(\mathrm{C}^{11}\right), 142.0\left(\mathrm{C}^{1}\right), 138.0$ $\left(\mathrm{C}^{10}\right), 135.4\left(\mathrm{C}^{13}\right), 130.3\left(\mathrm{C}^{15}\right), 130.1\left(\mathrm{C}^{6}\right), 129.2$ $\left(\mathrm{C}^{9}\right), 125.8\left(\mathrm{C}^{16}\right), 124.6\left(\mathrm{C}^{14}\right), 124.3\left(\mathrm{C}^{12}\right), 123.4$ $\left(\mathrm{C}^{2}, \mathrm{q},{ }^{3} J_{\mathrm{C}-\mathrm{F}}=5 \mathrm{~Hz}\right), 122.3\left(\mathrm{C}^{18}, \mathrm{q},{ }^{1} J_{\mathrm{C}-\mathrm{F}}=272 \mathrm{~Hz}\right)$, $120.4\left(\mathrm{C}^{8}\right), 119.3\left(\mathrm{C}^{3}, \mathrm{q},{ }^{2} J_{\mathrm{C}-\mathrm{F}}=32 \mathrm{~Hz}\right), 118.8\left(\mathrm{C}^{5}\right)$, $90.0\left(\mathrm{C}^{19}\right)$.

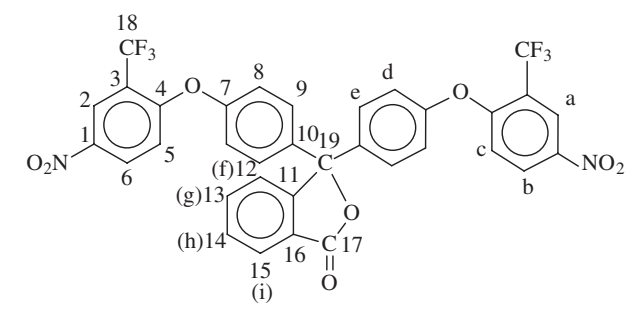

Elem. Anal. Calcd for $\mathrm{C}_{34} \mathrm{H}_{18} \mathrm{~F}_{6} \mathrm{O}_{8} \mathrm{~N}_{2}$ (696.52): C, $58.62 \%$; H, 2.60\%; N, 4.02\%. Found: C, 58.64\%; H, $2.61 \% ; \mathrm{N}, 4.02 \%$.

3,3-Bis[4-(4-amino-2-trifluoromethylphenoxy)phenyllphthalide (II). To a suspension solution of the purified dinitro compound $\mathbf{I}(21 \mathrm{~g}, 0.03 \mathrm{~mol})$ and $10 \%$ $\mathrm{Pd} / \mathrm{C}(0.2 \mathrm{~g})$ in ethanol $(150 \mathrm{~mL})$, hydrazine monohydrate $(7 \mathrm{~mL})$ was added dropwise to the stirred mixture at $70-80^{\circ} \mathrm{C}$ within $30 \mathrm{~min}$. After complete addition, the mixture was heated at reflux temperature for another $2 \mathrm{~h}$. The reaction solution was filtered hot to remove $\mathrm{Pd} / \mathrm{C}$, and the filtrate was then distilled to remove the solvent. The obtained mixture was poured into water to precipitate powder that was dried in vacuum to give white solid II $(17.4 \mathrm{~g}, 91 \%)$.

mp: $89-90^{\circ} \mathrm{C}$. IR (KBr): 3450, 3374, $3327(\mathrm{~N}-\mathrm{H}$ stretch), 1268, 1222, $1162,1120 \mathrm{~cm}^{-1}(\mathrm{C}-\mathrm{O}$ and $\mathrm{C}-$ F stretch). ${ }^{1} \mathrm{H}$ NMR (DMSO- $\left.d_{6}, \delta\right): 7.94$ (d, $J=7.65$ $\left.\mathrm{Hz}, 1 \mathrm{H}, \mathrm{H}_{\mathrm{i}}\right), 7.86\left(\mathrm{~m}, 2 \mathrm{H}, \mathrm{H}_{\mathrm{f}, \mathrm{g}}\right), 7.68(\mathrm{~m}, J=7.08$, $\left.7.08 \mathrm{~Hz}, 1 \mathrm{H}, \mathrm{H}_{\mathrm{h}}\right), 7.27\left(\mathrm{~d}, J=8.8 \mathrm{~Hz}, 4 \mathrm{H}, \mathrm{H}_{\mathrm{e}}\right), 6.92$ $\left(\mathrm{d}, J=2.6 \mathrm{~Hz}, 2 \mathrm{H}, \mathrm{H}_{\mathrm{a}}\right), 6.91(\mathrm{~d}, J=8.65 \mathrm{~Hz}, 2 \mathrm{H}$, $\left.\mathrm{H}_{\mathrm{c}}\right), 6.89\left(\mathrm{~d}, J=8.75 \mathrm{~Hz}, 4 \mathrm{H}, \mathrm{H}_{\mathrm{d}}\right), 6.82(\mathrm{~m}, J=8.75$ $\left.\mathrm{Hz}, 2 \mathrm{H}, \mathrm{H}_{\mathrm{b}}\right), 5.52\left(\mathrm{~s}, 4 \mathrm{H},-\mathrm{NH}_{2}\right) .{ }^{13} \mathrm{C}$ NMR (DMSO$\left.d_{6}, \delta\right): 168.7\left(\mathrm{C}^{17}\right), 158.5\left(\mathrm{C}^{4}\right), 151.7\left(\mathrm{C}^{11}\right), 146.0$ $\left(\mathrm{C}^{7}\right), 141.5\left(\mathrm{C}^{1}\right), 135.0\left(\mathrm{C}^{13}\right), 134.4\left(\mathrm{C}^{10}\right), 129.9$ $\left(\mathrm{C}^{15}\right), 128.3\left(\mathrm{C}^{9}\right), 125.5\left(\mathrm{C}^{16}\right), 124.4\left(\mathrm{C}^{14}\right), 124.3$ $\left(\mathrm{C}^{12}\right), 123.4\left(\mathrm{C}^{5}\right), 123.4\left(\mathrm{C}^{18}, \mathrm{q},{ }^{1} J_{\mathrm{C}-\mathrm{F}}=271 \mathrm{~Hz}\right)$, $121.5\left(\mathrm{C}^{3}, \mathrm{q},{ }^{2} J_{\mathrm{C}-\mathrm{F}}=30 \mathrm{~Hz}\right), 118.5\left(\mathrm{C}^{6}\right), 116.3\left(\mathrm{C}^{8}\right)$, $110.6\left(\mathrm{C}^{2}, \mathrm{q},{ }^{3} J_{\mathrm{C}-\mathrm{F}}=5 \mathrm{~Hz}\right), 90.5\left(\mathrm{C}^{19}\right)$.

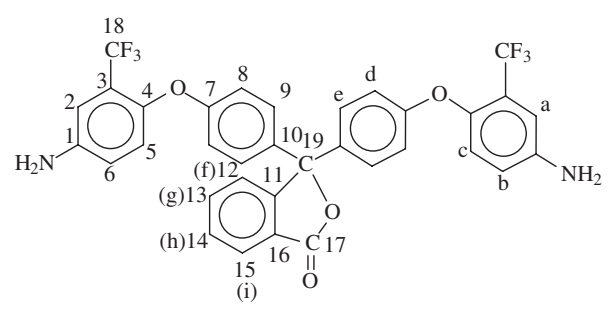

Elem. Anal. Calcd for $\mathrm{C}_{34} \mathrm{H}_{22} \mathrm{~F}_{6} \mathrm{O}_{4} \mathrm{~N}_{2}$ (636.55): C, $64.15 \%$; H, 3.48\%; N, 4.40\%. Found: C, 64.17\%; H, $3.50 \% ; \mathrm{N}, 4.40 \%$.

\section{Synthesis of Polyimides}

Thermal Imidization. Diamine II $(0.637 \mathrm{~g}$, $1 \mathrm{mmol}$ ) was dissolved in $6.7 \mathrm{~mL}$ of dried DMAc in a 50-mL flask. After the diamine was dissolved completely, $0.218 \mathrm{~g}(1 \mathrm{mmol}) \mathbf{I I I}_{\mathrm{a}}$ was added to it in one portion. The mixture was stirred at room temperature for $12 \mathrm{~h}$ to form a poly(amic acid) solution. Then the poly(amic acid) solution was poured into a glass culture dish $(\phi=9 \mathrm{~cm})$, which was placed in an $80^{\circ} \mathrm{C}$ oven for $1 \mathrm{~h}$ to remove the solvent. The semidried poly(amic acid) film was further dried and imidized by sequential heating at $120^{\circ} \mathrm{C}$ for $10 \mathrm{~min}, 150^{\circ} \mathrm{C}$ for $10 \mathrm{~min}, 180^{\circ} \mathrm{C}$ for $10 \mathrm{~min}, 210^{\circ} \mathrm{C}$ for $10 \mathrm{~min}$, and $250^{\circ} \mathrm{C}$ for $30 \mathrm{~min}$. By being soaked in water, a 
flexible polyimide film of $\mathbf{V}_{\mathrm{a}}(\mathbf{H})$ was self-stripped off from the glass surface. The inherent viscosity of $\mathbf{V}_{\mathrm{a}}(\mathbf{H})$ was $0.78 \mathrm{dL} / \mathrm{g}$ in DMAc at a $0.5 \mathrm{~g} / \mathrm{dL}$ concentration at $30^{\circ} \mathrm{C}$.

Chemical Imidization. In a similar method of synthesizing poly(amic acid) solution (as in A above), a 1.0-mL mixture of acetic anhydride and Py (volume ratio 2:1) then was added to the poly(amic acid) solution. The mixture was stirred at $80^{\circ} \mathrm{C}$ for $1 \mathrm{~h}$, and the resulting solution was poured into a glass culture dish $(\phi=9 \mathrm{~cm})$, which was placed in a $100^{\circ} \mathrm{C}$ oven for $30 \mathrm{~min}$ to remove the solvent. The semidried polyimide film was further processed by heating from $100^{\circ} \mathrm{C}$ to $250^{\circ} \mathrm{C}$ at a $20^{\circ} \mathrm{C} / 10 \mathrm{~min}$ rate to remove the residual solvent. The inherent viscosity of $\mathbf{V}_{\mathrm{a}}(\mathbf{C})$ was $0.71 \mathrm{dL} / \mathrm{g}$. All other polymers were synthesized by an analogous procedure as described.

IR (film): 1778, 1721 (imide $\mathrm{C}=\mathrm{O}), 1370(\mathrm{C}-\mathrm{N}$ stretch), 1093, $724 \mathrm{~cm}^{-1}$ (imide ring deformation). ${ }^{1} \mathrm{H}$ NMR (DMSO- $\left.d_{6}, \delta\right): 8.42\left(\mathrm{~s}, 2 \mathrm{H}, \mathrm{H}_{\mathrm{j}}\right), 8.01(\mathrm{~s}$, $\left.2 \mathrm{H}, \mathrm{H}_{\mathrm{a}}\right), 7.98\left(\mathrm{~d}, J=7.92 \mathrm{~Hz}, 2 \mathrm{H}, \mathrm{H}_{\mathrm{i}, \mathrm{f}}\right), 7.91(\mathrm{t}, J=$ $\left.7.34,7.16 \mathrm{~Hz}, 1 \mathrm{H}, \mathrm{H}_{\mathrm{g}}\right), 7.81(\mathrm{~d}, J=9.28 \mathrm{~Hz}, 2 \mathrm{H}$, $\left.\mathrm{H}_{\mathrm{b}}\right), 7.73\left(\mathrm{t}, J=7.36,7.14 \mathrm{~Hz}, 1 \mathrm{H}, \mathrm{H}_{\mathrm{h}}\right), 7.48(\mathrm{~d}$, $\left.J=8.44 \mathrm{~Hz}, 4 \mathrm{H}, \mathrm{H}_{\mathrm{e}}\right), 7.31\left(\mathrm{~d}, J=8.88 \mathrm{~Hz}, 2 \mathrm{H}, \mathrm{H}_{\mathrm{c}}\right)$, $7.23\left(\mathrm{~d}, J=8.44 \mathrm{~Hz}, 4 \mathrm{H}, \mathrm{H}_{\mathrm{d}}\right) .{ }^{13} \mathrm{C}$ NMR (DMSO$\left.d_{6}, \delta\right): 168.5\left(\mathrm{C}^{17}\right), 165.2\left(\mathrm{C}^{22}\right), 155.7\left(\mathrm{C}^{4}\right), 153.7$ $\left(\mathrm{C}^{7}\right), 151.3\left(\mathrm{C}^{11}\right), 137.0\left(\mathrm{C}^{21}\right), 136.7\left(\mathrm{C}^{1}\right), 135.2$ $\left(\mathrm{C}^{13}\right), 133.3\left(\mathrm{C}^{10}\right), 130.1\left(\mathrm{C}^{15}\right), 128.9\left(\mathrm{C}^{9}\right), 126.8$ $\left(\mathrm{C}^{20}\right), 126.2\left(\mathrm{C}^{16}\right), 125.7\left(\mathrm{C}^{14}\right), 124.6\left(\mathrm{C}^{12}\right), 124.3$ $\left(\mathrm{C}^{6}\right), 122.8\left(\mathrm{C}^{18}, \mathrm{q},{ }^{1} J_{\mathrm{C}-\mathrm{F}}=271 \mathrm{~Hz}\right), 120.1\left(\mathrm{C}^{5}\right)$, $119.7\left(\mathrm{C}^{3}, \mathrm{q},{ }^{2} J_{\mathrm{C}-\mathrm{F}}=32 \mathrm{~Hz}\right), 119.3\left(\mathrm{C}^{8}\right), 118.0\left(\mathrm{C}^{2}\right)$, $90.1\left(\mathrm{C}^{19}\right)$.

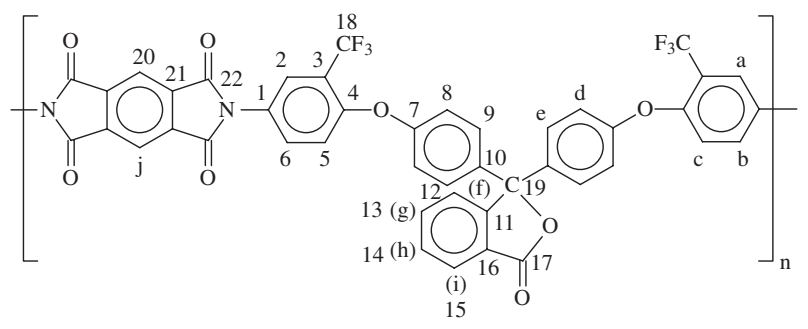

\section{Measurements}

IR spectra were recorded on a Horiba FourierTransform Infrared Spectrometer FT-720. Elemental analyses were run in a PerkinElmer Model 2400 $\mathrm{CHN}$ analyzer. ${ }^{1} \mathrm{H}$ and ${ }^{13} \mathrm{C}$ spectra were recorded on a Bruker AV-500 FT-NMR spectrometer. Inherent viscosities were determined at $0.5 \mathrm{~g} / \mathrm{dL}$ concentration using a Cannon-Fenske viscometer at $30^{\circ} \mathrm{C}$. The color intensity of the polymers was evaluated by a Macbeth Color-eye colorimeter. Measurements were performed with films, using an observational angle of $10^{\circ}$ and a CIE (Commission International de l'Eclairage)-D illuminant. A CIE LAB color difference equation was used. UV-vis spectra of the polymer films were re- corded on a Shimadzu UV-1601 UV-vis spectrophotometer. Mechanical properties of the films were measured with an Instron model 1130 tensile tester with a $5-\mathrm{kg}$ load cell at a crosshead speed of $5 \mathrm{~cm} /$ min on strips approximately $40-50 \mu \mathrm{m}$ thick and $0.5 \mathrm{~cm}$ wide with a $2-\mathrm{cm}$ gauge length. An average of at least five individual determinations was used. Glass transition temperatures $\left(T_{\mathrm{g}}\right)$ were measured on TA Instruments DSC 2010 at the rate of $15^{\circ} \mathrm{C} / \mathrm{min}$ in flowing nitrogen $\left(40 \mathrm{~cm}^{3} / \mathrm{min}\right) . T_{\mathrm{g}}$ were read as the midpoint of the heat capacity jump and were taken from the second heating scan after a quick cooling down from $400{ }^{\circ} \mathrm{C}$. Thermogravimetry analysis (TGA) was conducted with a TA Instruments TGA 2050. Experiments were carried out on 9-11-mg film samples heated in flowing nitrogen or air $\left(90 \mathrm{~cm}^{3} /\right.$ min) at a heating rate of $20^{\circ} \mathrm{C} / \mathrm{min}$. Dielectric constants of the polymer films were tested by the parallel-plate capacitor method with a Hewlett Packard 4194A dielectric analyzer. Gold electrodes were vacuum-deposited on both surfaces of dried films. Experiments were performed at $25^{\circ} \mathrm{C}$ in a dry chamber. The equilibrium moisture absorption was determined by the weighing of the changes in vacuum-dried film specimens before and after immersion in deionized water at $25^{\circ} \mathrm{C}$ for $3 \mathrm{~d}$.

\section{RESULTS AND DISCUSSION}

\section{Monomer Synthesis}

A fluorinated diamine II was prepared through the nucleophilic substitution reaction of 2-chloro-5-nitrobenzotrifluoride with phenolphthalein, followed by catalytic reduction with hydrazine and $\mathrm{Pd} / \mathrm{C}$ in refluxing ethanol as shown in Scheme 1. Due to the electron withdrawing of $\mathrm{CF}_{3}$ groups, both the reaction temperature and the amount of $\mathrm{K}_{2} \mathrm{CO}_{3}$ of nucleophilic substitution reaction could be reduced to avoid the side reaction of phthalide group. FT IR, NMR, and elemental analysis were used to confirm the structures of the intermediate $\mathbf{I}$ and diamine monomer II. Figure 1 shows the FT IR spectra of the monomer I and II. The nitro group of compound I gave two characteristic bands at 1530 and $1350 \mathrm{~cm}^{-1}\left(\mathrm{NO}_{2}\right.$ asymmetric and symmetric stretching). After reduction, the characteristic absorptions of the nitro group disappeared, and the amino group showed the pair of $\mathrm{N}-\mathrm{H}$ stretching bands in the region of $3300-3500 \mathrm{~cm}^{-1}$.

Figure 2 and Figure 3 present the ${ }^{1} \mathrm{H}$ and ${ }^{13} \mathrm{C}$ NMR spectra of the monomer I and II. The absorption signals of aromatic protons of $\mathbf{I}$ appeared in the region of 7.2-8.5 ppm, and those of II shifted to higher field between 6.8-7.9 ppm. In ${ }^{1} \mathrm{H}$ NMR spectrum of $\mathbf{I}$, the protons $\mathrm{H}_{\mathrm{a}}$ and $\mathrm{H}_{\mathrm{b}}$ resonated at the farthest downfield due to the inductive effect of electron withdrawing 
C.-P. YANG, H.-C. CHIANG, and Y.-Y. SU
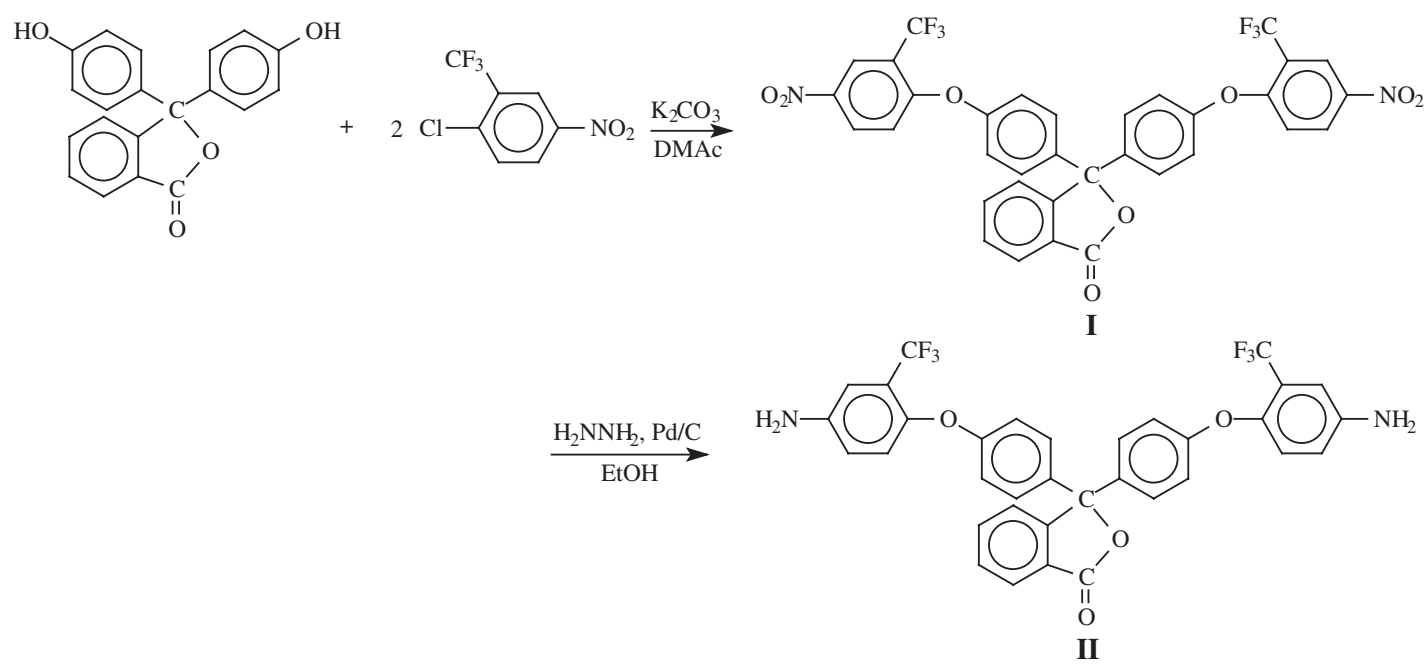

Scheme 1. Synthesis of 3F-diamine II.

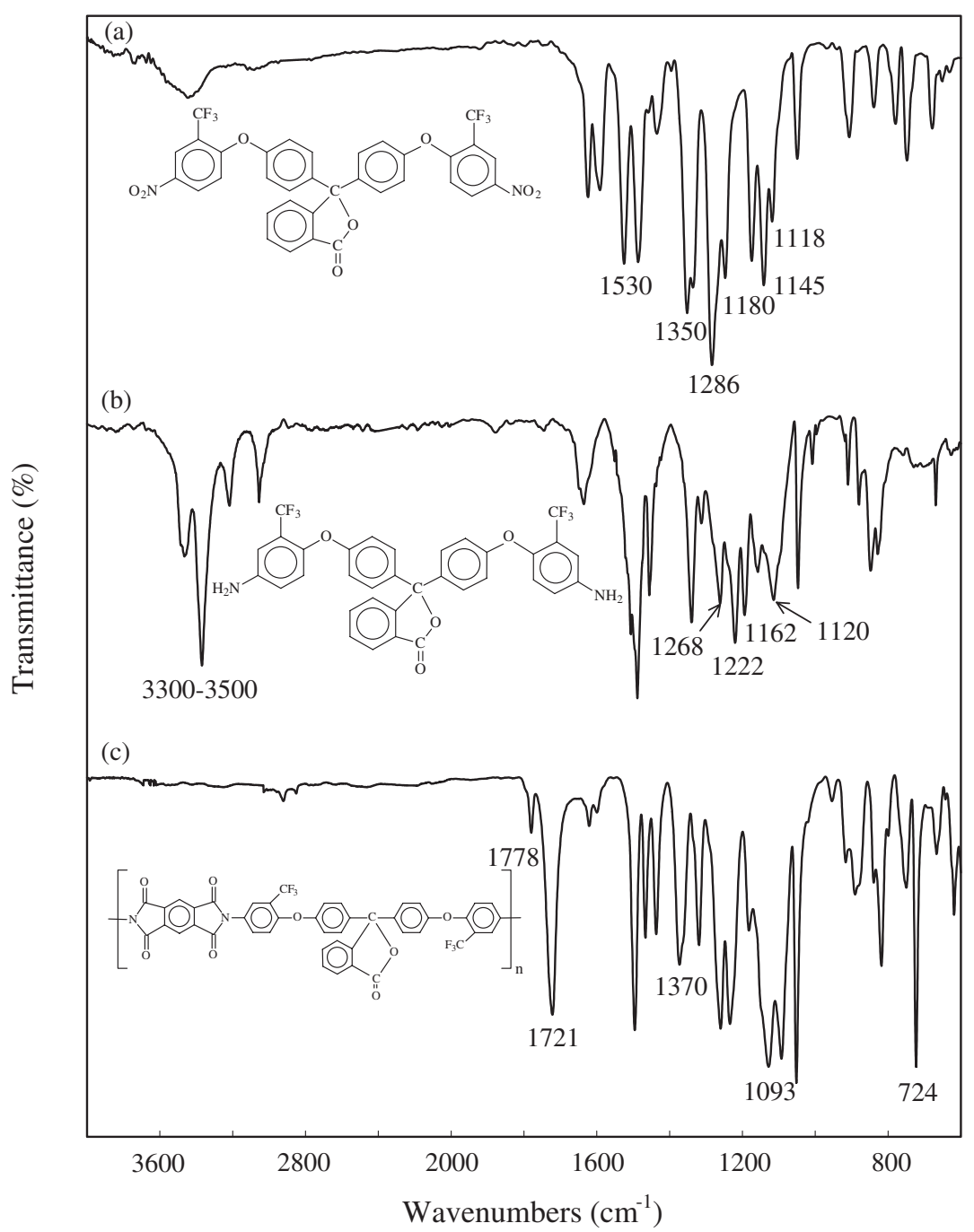

Figure 1. FT IR spectra of (a) 3F-dinitro compound I, (b) 3F-diamine II and (c) polyimide $\mathbf{V}_{\mathrm{a}}$.

$-\mathrm{NO}_{2}$ and $-\mathrm{CF}_{3}$ groups; the protons $\mathrm{H}_{\mathrm{f}}$ and $\mathrm{H}_{\mathrm{i}}$ adjacent to the ester group also resonated at the more downfield, due to the inductive effect and resonance. The chemical shifts of $\mathrm{H}_{\mathrm{d}}$ and $\mathrm{H}_{\mathrm{c}}$ presented in the up- field shifting of their positions might be due to the electron-donating phenoxy groups in the ortho positions. After reduction, the protons $\mathrm{H}_{\mathrm{f}-\mathrm{i}}$ adjacent to the ester group resonated at the farthest downfield, 


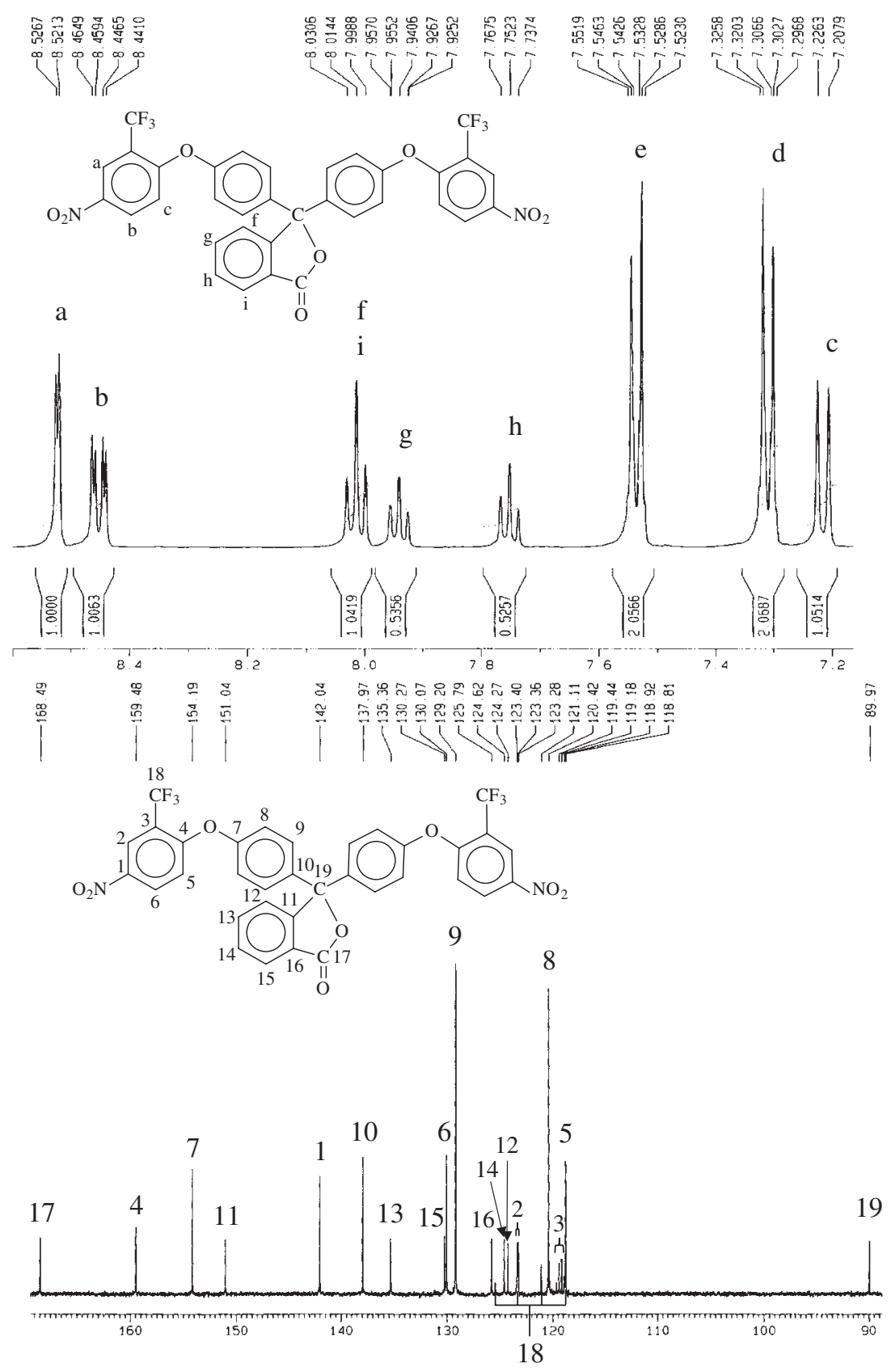

Figure 2. The ${ }^{1} \mathrm{H}$ and ${ }^{13} \mathrm{C}$ NMR spectra of 3F-dinitro compound I in DMSO- $d_{6}$.

due to the inductive effect and resonance; the protons $\mathrm{H}_{\mathrm{a}}$ and $\mathrm{H}_{\mathrm{b}}$ of II shifted to the upfield due to the electron donating effect of the amino group.

In ${ }^{13} \mathrm{C}$ NMR spectra, all the carbon-13 atoms in I and II showed 19 main signals in the region of 90$170 \mathrm{ppm}$, including 1 signal of carbonyl of the ester group and 16 signals of carbon of benzene. The ${ }^{13} \mathrm{C}$ NMR spectrum of I shows three quartets because of the heteronuclear ${ }^{13} \mathrm{C}-{ }^{19} \mathrm{~F}$ coupling. The large quartet centered at about $122 \mathrm{ppm}$ was due to the $\mathrm{CF}_{3}$ carbon. The one-bond $\mathrm{C}-\mathrm{F}$ coupling constant in this case was about $272 \mathrm{~Hz}$. The $\mathrm{CF}_{3}$-attached carbon $\left(\mathrm{C}^{3}\right)$ also showed a clear quartet centered at about $119 \mathrm{ppm}$ with a smaller coupling constant of about $32 \mathrm{~Hz}$ due to two- bond $\mathrm{C}-\mathrm{F}$ coupling. Besides, the $\mathrm{C}^{2}$ carbon (ortho to the $\mathrm{CF}_{3}$ group) also had its resonance split by the three fluorines (three-bond coupling). The close quartet had an even smaller coupling constant $(\mathrm{ca} .5 \mathrm{~Hz})$ because the interaction operated over more bonds. Similar splitting patterns (with ${ }^{1} J_{\mathrm{C}-\mathrm{F}}=271 \mathrm{~Hz},{ }^{2} J_{\mathrm{C}-\mathrm{F}}=30$ $\mathrm{Hz}$, and ${ }^{3} J_{\mathrm{C}-\mathrm{F}}=5 \mathrm{~Hz}$ ) were also found in ${ }^{13} \mathrm{C}$ NMR spectrum of II (Figure 3). All the spectroscopic data obtained were in good agreement with the expected structures.

\section{Polymer Synthesis}

All the polymers $\mathbf{V}$ series had been synthesized in two steps by the polymerization reaction of diamine 


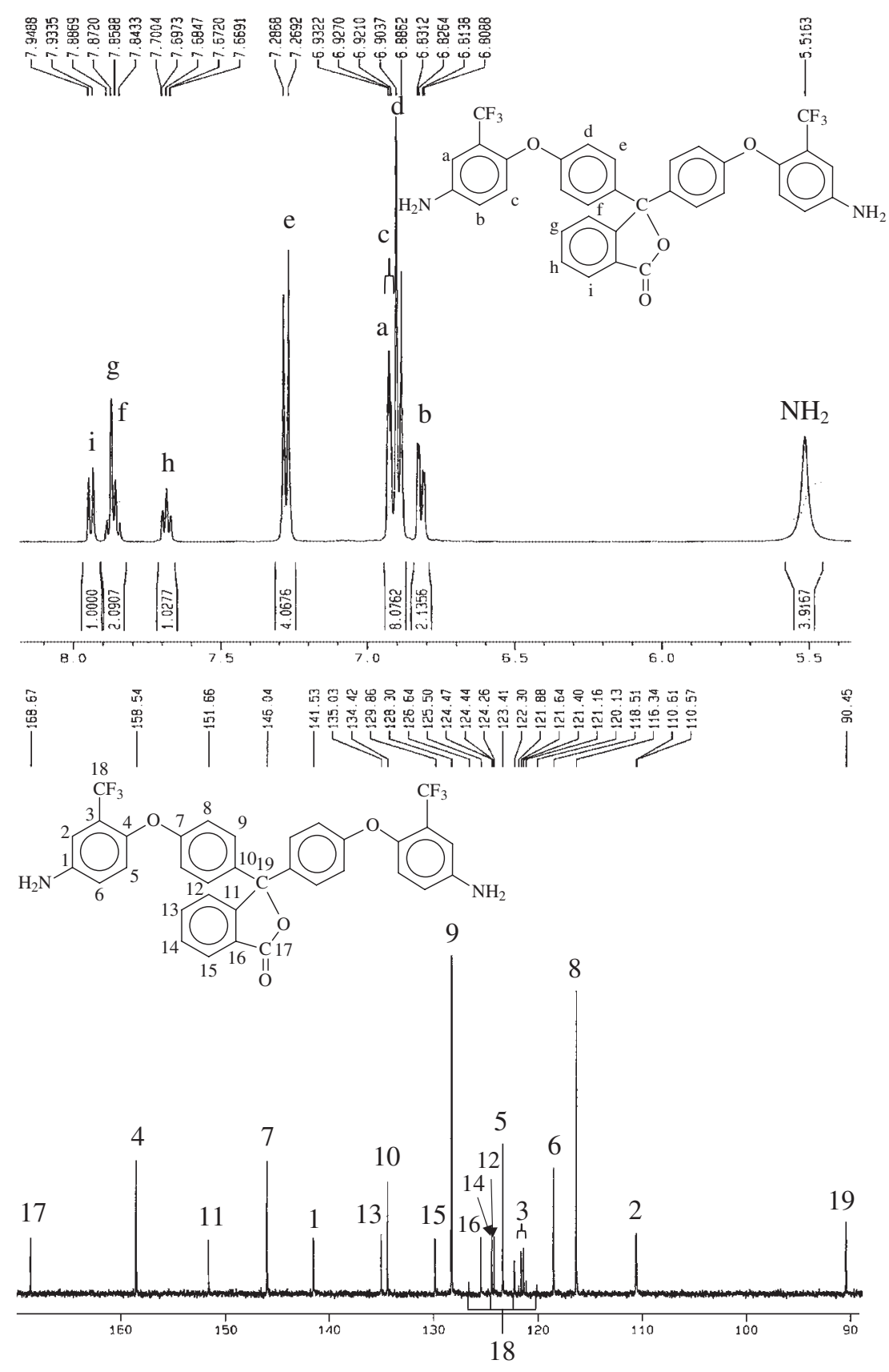

Figure 3. The ${ }^{1} \mathrm{H}$ and ${ }^{13} \mathrm{C}$ NMR spectra of 3F-diamine II in DMSO- $d_{6}$.

II with six dianhydrides ( III $\left._{\mathrm{a}-\mathrm{f}}\right)$ to form poly(amic acid)s $\mathbf{I} \mathbf{V}_{\mathrm{a}-\mathrm{f}}$, followed by thermal or chemical imidization to obtain corresponding polyimides $\mathbf{V}_{\mathrm{a}-\mathrm{f}}$, as shown in Scheme 2. The amino groups in diamine II were less basic than a normal aromatic diamine because of the inductive deactive of the $\mathrm{CF}_{3}$ group, a result confirmed by the slow polymerization rate inferred from the data in Figure 4. As shown in Figure 4, the reaction of PMDA with fluorinated II proceeded relatively slowly and the inherent viscosity of poly(amic acid) reached $0.72 \mathrm{dL} / \mathrm{g}$ after $5 \mathrm{~h}$. After this point, inherent viscosity increased slowly; polymerization nearly ceased and no increase in inherent viscosity $(0.82 \mathrm{dL} / \mathrm{g})$ was observed after $8 \mathrm{~h}$. In contrast, the re- action of PMDA with $\mathbf{I I}^{\prime}$ proceeded relatively fast and its inherent viscosity increased fast and the inherent viscosity reached $1.06 \mathrm{dL} / \mathrm{g}$ within $50 \mathrm{~min}$.

IR spectroscopy allows monitoring of the imide ring formation during thermal curing. The typical FT IR spectra of polyimide $\mathbf{V}_{\mathrm{a}}$ are shown in Figure 1. As the poly(amic acid) was converted into the polyimide, the characteristic absorption bands of the imide ring were observed near 1778 and 1721 (asymmetrical and symmetrical $\mathrm{C}=\mathrm{O}$ stretching vibration), 1370 (C-N stretching vibration), and 1093 and $724 \mathrm{~cm}^{-1}$ (imide ring deformation), together with some strong absorption bands in the region of $1100-1300 \mathrm{~cm}^{-1}$ due to the $\mathrm{C}-\mathrm{O}$ and $\mathrm{C}-\mathrm{F}$ stretching. The disappearance 


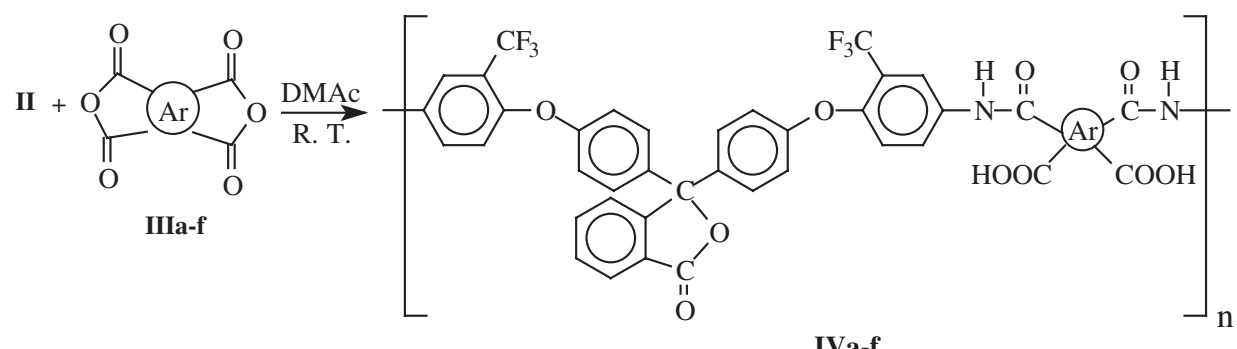

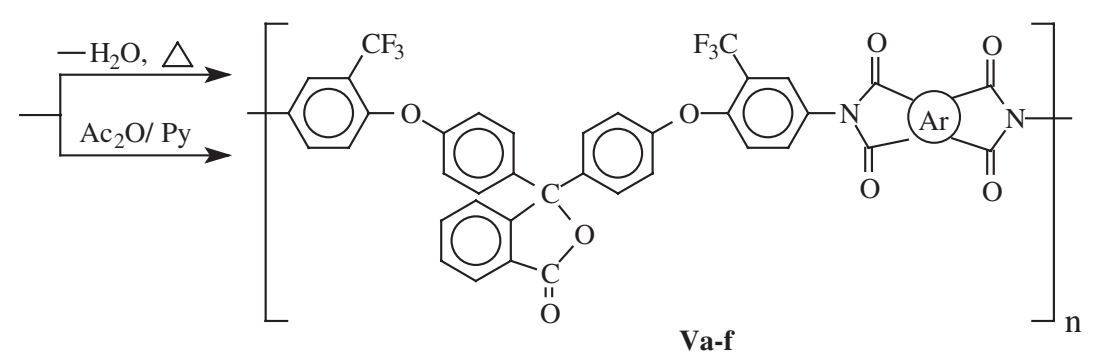

Ar:<smiles>Cc1cc(C)c(C)cc1C</smiles><smiles>Cc1ccc(S(=O)(=O)c2ccc(C)c(C)c2)cc1C</smiles>

d<smiles>Cc1ccc(C(=O)c2ccc(C)c(C)c2)cc1C</smiles>

b<smiles>Cc1ccc(Oc2ccc(C)c(C)c2)cc1C</smiles>

$\mathrm{e}$<smiles>Cc1ccc(-c2ccc(C)c(C)c2)cc1C</smiles><smiles>Cc1ccc(C(c2ccc(C)c(C)c2)(C(F)(F)F)C(F)(F)F)cc1C</smiles>

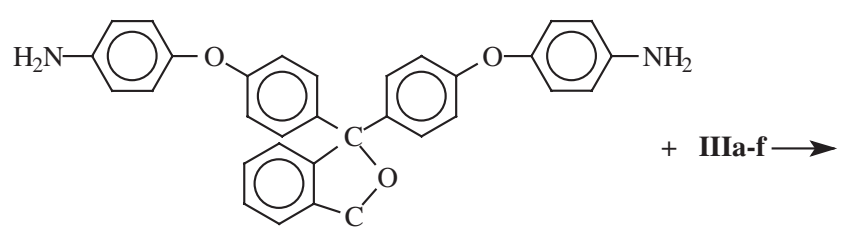

$\mathrm{O}$<smiles>Cc1ccc(Oc2ccc(C3(c4ccc(Oc5ccc(-n6c(=O)c7c8c(c(=O)c=7c6=O)C(=O)N(C)CC8(C)C)cc5)cc4)OC(=O)c4ccccc43)cc2)cc1</smiles>

Scheme 2. Synthesis of the polyimmides.

of amide and carboxyl bands indicates a virtually complete conversion of the poly(amic acid) precursor into polyimide.

The typical NMR spectra of soluble polypyromellitimide $\mathbf{V}_{\mathrm{a}}$ are shown in Figure 5. In ${ }^{1} \mathrm{H}$ NMR spectrum, all the protons resonated in the region of 7.0$8.5 \mathrm{ppm}$. The protons $\mathrm{H}_{\mathrm{j}}$ and $\mathrm{H}_{\mathrm{f}, \mathrm{i}}$ adjacent to the imide ring and ester group resonated at the farthest downfield region, owing to the inductive effect and resonance. $\mathrm{H}_{\mathrm{a}}$ also resonated at lower field because of closing to the electron withdrawing $\mathrm{CF}_{3}$ group and imide ring. $\mathrm{H}_{c}$ and $\mathrm{H}_{\mathrm{d}}$ showed at high filed due to the electron donating property of aromatic ether. The ${ }^{13} \mathrm{C}$ NMR spectrum of $\mathbf{V}_{\mathrm{a}}$ exhibited 22 signals in the range of $90-169 \mathrm{ppm}$, and carbon $\mathrm{C}^{17}$ of the ester group and $\mathrm{C}^{22}$ of the carbonyl group were evidenced in the downfield region. Furthermore, the splitting of the ${ }^{13} \mathrm{C}$ signals caused by couplings between carbon and fluorine also could be observed in the spectrum. The magnitudes of the one-bond and two-bond carbon-fluorine couplings ${ }^{1} J_{\mathrm{CF}}$ and ${ }^{2} J_{\mathrm{CF}}$ are listed in Table I. Above-cited results evidenced that series $\mathbf{V}$ had been synthesized successfully. 


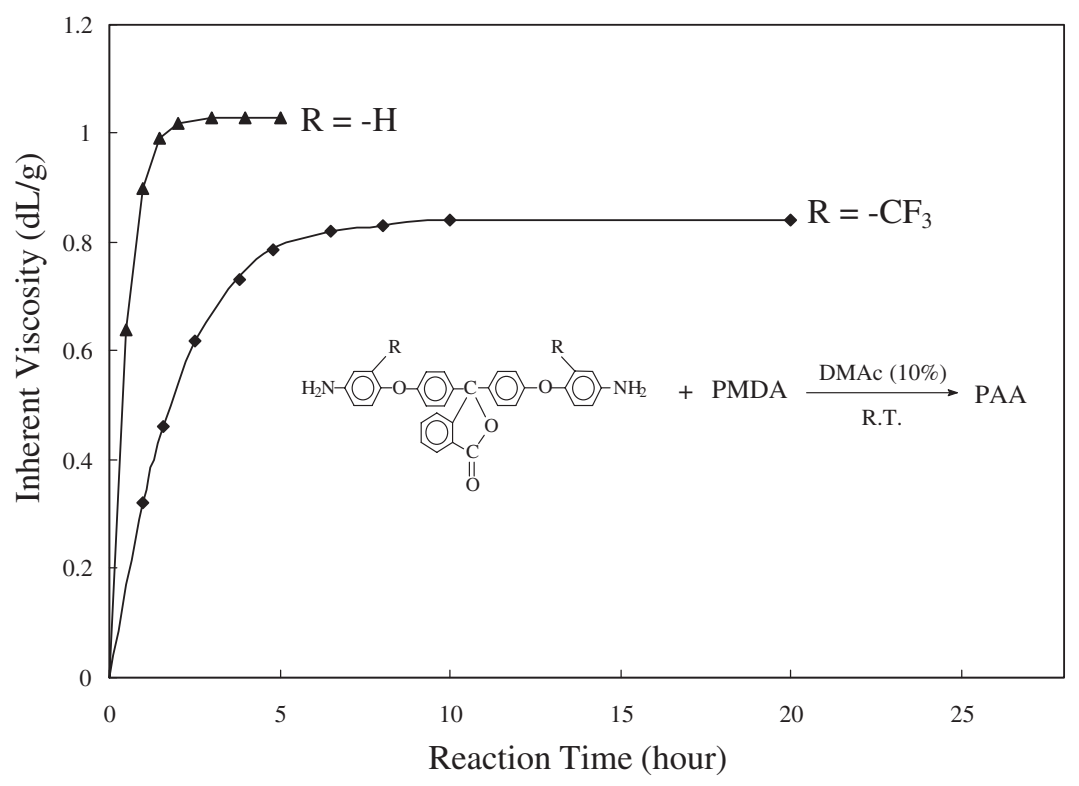

Figure 4. Viscosity change of poly(amic acid)s prepared in DMAc at $10 \%$ solid content at room temperature.

Table I. Inherent viscosity of poly(amic acid)s and polyimides and elemental analysis of the polyimides

\begin{tabular}{|c|c|c|c|c|c|c|c|c|}
\hline \multicolumn{2}{|c|}{ Poly(amic acid) } & \multicolumn{2}{|c|}{ Polyimide } & \multirow{2}{*}{$\begin{array}{l}\text { Formula } \\
\qquad M_{\mathrm{w}}\end{array}$} & \multicolumn{4}{|c|}{ Elemental analysis $(\%)$} \\
\hline Code & $\begin{array}{c}\eta_{\text {inh }} \\
(\mathrm{dL} / \mathrm{g})^{\mathrm{a}}\end{array}$ & Code & $\begin{array}{c}\eta_{\text {inh }} \\
(\mathrm{dL} / \mathrm{g})^{\mathrm{a}}\end{array}$ & & & $\mathrm{C}$ & $\mathrm{H}$ & $\mathrm{N}$ \\
\hline \multirow[t]{2}{*}{$\mathbf{I V}_{\mathrm{a}}$} & \multirow[t]{2}{*}{0.82} & \multirow[t]{2}{*}{$\mathbf{V}_{\mathrm{a}}$} & \multirow[t]{2}{*}{0.78} & \multirow{2}{*}{$\begin{array}{c}\left(\mathrm{C}_{44} \mathrm{H}_{20} \mathrm{O}_{8} \mathrm{~N}_{2} \mathrm{~F}_{6}\right)_{n} \\
(818.64)_{n}\end{array}$} & Calcd & 64.56 & 2.46 & 3.42 \\
\hline & & & & & Found & 64.58 & 2.47 & 3.42 \\
\hline \multirow[t]{2}{*}{$\mathbf{I} \mathbf{V}_{\mathrm{b}}$} & \multirow[t]{2}{*}{0.98} & \multirow[t]{2}{*}{$\mathbf{V}_{\mathrm{b}}$} & \multirow[t]{2}{*}{0.95} & \multirow{2}{*}{$\begin{array}{c}\left(\mathrm{C}_{51} \mathrm{H}_{24} \mathrm{O}_{9} \mathrm{~N}_{2} \mathrm{~F}_{6}\right)_{n} \\
(922.75)_{n}\end{array}$} & Calcd & 66.38 & 2.62 & 3.04 \\
\hline & & & & & Found & 66.37 & 2.60 & 3.05 \\
\hline \multirow[t]{2}{*}{$\mathbf{I} \mathbf{V}_{\mathrm{c}}$} & \multirow[t]{2}{*}{0.84} & \multirow[t]{2}{*}{$\mathbf{V}_{\mathrm{c}}$} & \multirow[t]{2}{*}{0.82} & \multirow{2}{*}{$\begin{array}{c}\left(\mathrm{C}_{50} \mathrm{H}_{24} \mathrm{O}_{8} \mathrm{~N}_{2} \mathrm{~F}_{6}\right)_{n} \\
(894.74)_{n}\end{array}$} & Calcd & 67.12 & 2.70 & 3.13 \\
\hline & & & & & Found & 67.10 & 2.69 & 3.12 \\
\hline \multirow[t]{2}{*}{$\mathbf{I V} \mathbf{d}_{\mathrm{d}}$} & \multirow[t]{2}{*}{0.71} & \multirow[t]{2}{*}{$\mathbf{V}_{\mathrm{d}}$} & \multirow[t]{2}{*}{0.68} & \multirow{2}{*}{$\begin{array}{c}\left(\mathrm{C}_{50} \mathrm{H}_{24} \mathrm{O}_{10} \mathrm{~N}_{2} \mathrm{~F}_{6} \mathrm{~S}_{1}\right)_{n} \\
(958.80)_{n}\end{array}$} & Calcd & 62.64 & 2.52 & 2.92 \\
\hline & & & & & Found & 62.61 & 2.50 & 2.93 \\
\hline \multirow[t]{2}{*}{$\mathbf{I} \mathbf{V}_{\mathrm{e}}$} & \multirow[t]{2}{*}{0.73} & \multirow[t]{2}{*}{$\mathbf{V}_{\mathrm{e}}$} & \multirow[t]{2}{*}{0.70} & \multirow{2}{*}{$\begin{array}{c}\left(\mathrm{C}_{50} \mathrm{H}_{24} \mathrm{O}_{9} \mathrm{~N}_{2} \mathrm{~F}_{6}\right)_{n} \\
(910.74)_{n}\end{array}$} & Calcd & 65.94 & 2.66 & 3.08 \\
\hline & & & & & Found & 65.93 & 2.66 & 3.09 \\
\hline \multirow[t]{2}{*}{$\mathbf{I V} \mathbf{V}_{\mathrm{f}}$} & \multirow[t]{2}{*}{0.66} & \multirow[t]{2}{*}{$\mathbf{V}_{\mathrm{f}}$} & \multirow[t]{2}{*}{0.63} & \multirow{2}{*}{$\begin{array}{c}\left(\mathrm{C}_{53} \mathrm{H}_{24} \mathrm{O}_{8} \mathrm{~N}_{2} \mathrm{~F}_{12}\right)_{n} \\
(1044.76)_{n}\end{array}$} & Calcd & 60.93 & 2.32 & 2.68 \\
\hline & & & & & Found & 60.90 & 2.30 & 2.66 \\
\hline
\end{tabular}

${ }^{\mathrm{a}}$ Measured at a polymer concentration of $0.5 \mathrm{~g} / \mathrm{dL}$ in DMAc at $30{ }^{\circ} \mathrm{C}$. ${ }^{\mathrm{b}}$ Polyimides were obtained by the thermal imidization method.

\section{Properties of Polymer}

The solubility of these polyimides was tested in various organic solvents, and the results are summarized in Table II. In this study polyimides $\mathbf{V}_{\mathrm{a}-\mathrm{f}}$ were soluble in aprotic polar solvents such as NMP, DMAc, DMF, and DMSO and were also soluble in less polar solvents like $m$-cresol, pyridine, and dioxane. The good solubility of $\mathbf{V}$ might be due to the introduction of bulky asymmetry phthalide, aryl ether unit and the pendent of $\mathrm{CF}_{3}$ groups along the polymer bockbone. The solubility of $\mathbf{V}_{\mathrm{d}-\mathrm{f}}$ in $m$-cresol was better than that of $\mathbf{V}_{\mathrm{a}-\mathrm{c}}$ because of the flexible ether linkage or hindered isopropylidene and sulfone groups in the dianhydride moiety. Compared with polyimides VI, V showed better solubility. The higher solubility of $\mathbf{V}$ series was attributed to the presence of bulky trifluoromethyl groups, which increased the disorder in the chains and hindered dense chain stacking, thereby reduced the interchain interactions to enhance solubility.

The color intensities of the polyimides were elucidated from the yellowness $\left(b^{*}\right)$, redness $\left(a^{*}\right)$ and lightness $\left(L^{*}\right)$ indices observed by a Macbeth color-eye colorimeter. For comparison, the corresponding polyimides VI without the $\mathrm{CF}_{3}$ groups were also prepared and characterized by their color intensity. The color coordinates of these polymers are given in Table III. Figure 6 also shows that the color intensity of polyimides was affected by dianhydride moieties with decreased in the following decreasing order: PMDA > BTDA $>$ BPDA $>$ DSDA $>$ ODPA $>6$ FDA. $\quad \mathbf{V}_{c-f}$ displayed lighter color than the others. As compared 


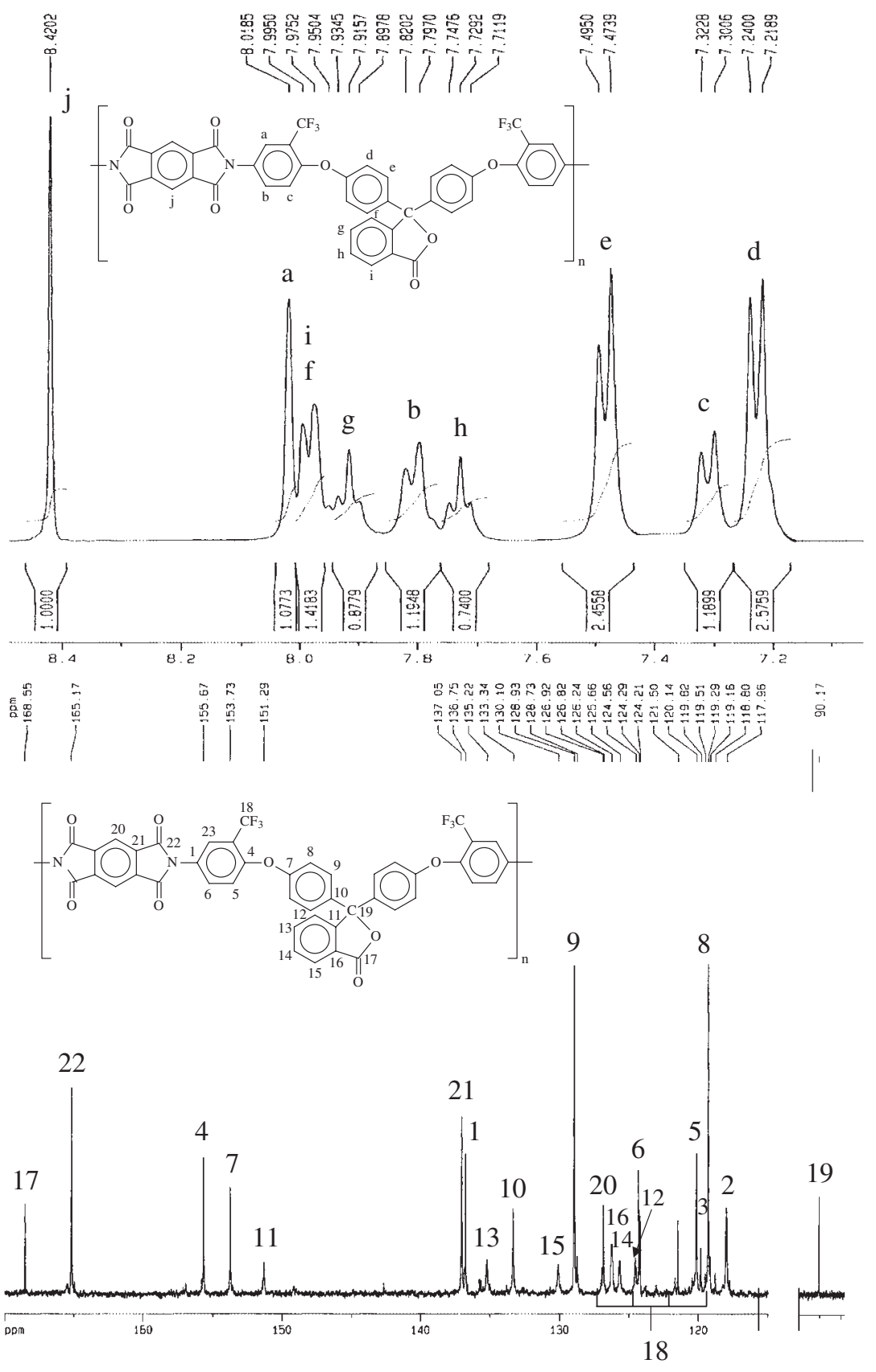

Figure 5. The ${ }^{1} \mathrm{H}$ and ${ }^{13} \mathrm{C}$ NMR spectra of polyimide $\mathbf{V}_{\mathrm{a}}$ in DMSO- $d_{6}$.

series $\mathbf{V}$ polymers with series $\mathbf{V I}$ polymers, the results indicate that $\mathbf{V}$ series showed a lower $b^{*}$ value (a yellowness index) in contrast with the corresponding VI.

The color intensities of the polyimides could also be elucidated from the cutoff wavelength observed in the UV-vis absorption spectra. Figure 7 shows the UV-vis spectra of the polyimide films, and the cutoff wavelengths from these spectra are listed in Table III. V series had cutoff wavelengths in the range of 338-388 nm. $\mathbf{V}_{\mathrm{c}-\mathrm{f}}$ were lightly colored and exhibited cutoffs at wavelength shorter than $380 \mathrm{~nm}$. In particular, 6FDA and ODPA produced fairly transparent and almost colorless polyimide films in contrast to other dianhydrides. On comparing thermal imidized polymers with chemical imidized ones, they showed a similar $b^{*}$ value and cutoff wavelength. This might be indicated that the $\mathbf{V}(\mathbf{H})$ series possesses the ability of an anti-thermaloxidation to prevent from coloration. Consistent with the results obtained from the colorimeter, all the fluorinated polyimides revealed a shorter cutoff wavelength than their respective nonfluorinated analogues. The light color of the polyimides with the $\mathrm{CF}_{3}$ groups in their diamine moieties could be explained from the decreased intermolecular interactions. The bulky and electron-withdrawing $\mathrm{CF}_{3}$ group in diamine II was effective in decreasing CTC formation between polymer chains through steric hindrance and the inductive effect (by decreasing the 
Table II. Solubility behavior of the polyimides ${ }^{\mathrm{a}}$

\begin{tabular}{cccccccc}
\hline \multirow{2}{*}{ Polymer $^{\mathrm{b}}$} & \multicolumn{7}{c}{ Solvent $^{\mathrm{c}}$} \\
\cline { 2 - 8 } & NMP & DMAc & DMF & DMSO & Py & $m$-Cresol & Dioxane \\
\hline $\mathbf{V}_{\mathrm{a}}$ & ++ & $(++)$ & ++ & ++ & ++ & + & + \\
$\mathbf{V}_{\mathrm{b}}$ & ++ & $(++)$ & ++ & ++ & ++ & + & + \\
$\mathbf{V}_{\mathrm{c}}$ & ++ & $(++)$ & ++ & ++ & ++ & + & + \\
$\mathbf{V}_{\mathrm{d}}$ & ++ & $(++)$ & ++ & ++ & ++ & ++ & + \\
$\mathbf{V}_{\mathrm{e}}$ & ++ & $(++)$ & ++ & ++ & ++ & ++ & + \\
$\mathbf{V}_{\mathrm{f}}$ & ++ & $(++)$ & ++ & ++ & ++ & ++ & + \\
& & & & & & & \\
$\mathbf{V I}_{\mathrm{a}}$ & - & - & - & - & - & - & - \\
$\mathbf{V I}_{\mathrm{b}}$ & - & - & - & - & - & - & - \\
$\mathbf{V I}_{\mathrm{c}}$ & - & - & - & - & - & - & - \\
$\mathbf{V I}_{\mathrm{d}}$ & + & + & - & - & + & - & - \\
$\mathbf{V I}_{\mathrm{e}}$ & ++ & + & + & - & + & + & - \\
$\mathbf{V I}_{\mathrm{f}}$ & ++ & ++ & ++ & + & ++ & ++ & + \\
\hline
\end{tabular}

${ }^{a}$ Qualitative solubility was determined with $10 \mathrm{mg}$ of polymer in $1 \mathrm{~mL}$ of solvent: ++ , soluble at room temperature; + , soluble on heating; S, swelling or partially soluble; - , insoluble even on heating. ${ }^{b}$ Polyimides were obtained by the thermal imidization method. ${ }^{\mathrm{C}} \mathrm{NMP}: \mathrm{N}$-methyl-2-pyrrolidone; DMAc: $N, N$-dimethylacetamide; DMF: $N, N$-dimethylformamide; DMSO: dimethyl sulfoxide; Py: pyridine. ${ }^{\mathrm{d}}$ The solubility was determined at $10 \%$ solid content.

electron-donating property of diamine moieties). The good optical transparency and lighter color of the ODPA- and 6FDA-derived polyimide films result from the decrease in the intermolecular CTC interaction and electron conjugation by the aromatic ether and the bulky $-\mathrm{C}\left(\mathrm{CF}_{3}\right)_{2}-$.

All the polyimides $\mathbf{V}_{\mathrm{a}-\mathrm{f}}$ could afford good-quality films. These films were subjected to a tensile test, and their tensile properties are summarized in Table IV. These films had strengths at break of $105-125 \mathrm{MPa}$, elongations at break of 9-12\%, and initial modulus of 2.35-2.65 GPa. $\mathbf{V}_{\mathrm{a}}$ and $\mathbf{V}_{\mathrm{c}}$ exhibited better tensile properties due to the rigidity character of their dianhydride moieties. $\mathbf{V}_{\mathrm{b}}$ had the best tensile property. This might be attributable to the formation of some intermolecular links of the $\mathrm{C}=\mathrm{O}$ group of BTDA during the thermal imidization.

The thermal behavior data of all the fluorinated polymers are presented in Table V. DSC experiments were conducted at a heating rate of $15^{\circ} \mathrm{C} / \mathrm{min}$ in nitrogen. Rapid cooling from $400{ }^{\circ} \mathrm{C}$ to room temperature produced predominantly amorphous samples, so the glass transition temperatures $\left(T_{\mathrm{g}}\right)$ of all the polymer could be easily read in the subsequent heating DSC traces. The $T_{\mathrm{g}}$ values of these polyimides $\mathbf{V}_{\mathrm{a}-\mathrm{f}}$ were in the range of $259-320^{\circ} \mathrm{C}$, depending on the structure of the dianhydride component and decreasing with the increasing flexibility of the polymer backbones. As expected, $\mathbf{V}_{\mathrm{e}}$ obtained from ODPA showed the lowest $T_{\mathrm{g}}$ due to the presence of a flexible ether
Table III. Color coordinates and cut-off wavelength $\left(\omega_{0}\right)$ from UV-vis spectra for both $\mathbf{V}$ and VI series polyimides films

\begin{tabular}{|c|c|c|c|c|c|}
\hline \multirow{2}{*}{ Polymer } & \multicolumn{3}{|c|}{ Color coordinates ${ }^{\mathrm{a}}$} & \multirow{2}{*}{$\begin{array}{c}\omega_{0} \\
(\mathrm{~nm})^{\mathrm{b}}\end{array}$} & \multirow{2}{*}{$\begin{array}{l}\text { Film } \\
\text { thickness } \\
\quad(\mu \mathrm{m})\end{array}$} \\
\hline & $b$ & $a$ & $L$ & & \\
\hline Paper & 0.0 & 0.0 & 100 & & \\
\hline $\mathbf{V}_{\mathrm{a}}(\mathrm{H})$ & 43.6 & -10.5 & 97.8 & 388 & 34 \\
\hline $\mathbf{V}_{\mathrm{b}}(\mathrm{H})$ & 30.8 & -9.8 & 98.6 & 385 & 31 \\
\hline $\mathbf{V}_{\mathrm{c}}(\mathrm{H})$ & 24.4 & -6.7 & 98.6 & 380 & 37 \\
\hline $\mathbf{V}_{\mathrm{d}}(\mathrm{H})$ & 22.7 & -7.4 & 98.6 & 374 & 35 \\
\hline $\mathbf{V}_{\mathrm{e}}(\mathrm{H})$ & 10.0 & -4.3 & 99.8 & 357 & 40 \\
\hline $\mathbf{V}_{\mathrm{f}}(\mathrm{H})$ & 9.8 & -3.2 & 99.1 & 338 & 38 \\
\hline $\mathbf{V}_{\mathrm{a}}(\mathrm{C})$ & 40.3 & -6.8 & 98.5 & 384 & 35 \\
\hline $\mathbf{V}_{\mathrm{b}}(\mathrm{C})$ & 26.4 & -5.7 & 98.6 & 382 & 29 \\
\hline $\mathbf{V}_{\mathrm{c}}(\mathrm{C})$ & 21.2 & -4.4 & 98.7 & 375 & 34 \\
\hline $\mathbf{V}_{\mathrm{d}}(\mathrm{C})$ & 19.2 & -5.3 & 98.5 & 368 & 39 \\
\hline $\mathbf{V}_{\mathrm{e}}(\mathrm{C})$ & 9.6 & -3.8 & 99.7 & 353 & 37 \\
\hline $\mathbf{V}_{\mathrm{f}}(\mathrm{C})$ & 8.4 & -3.4 & 98.3 & 335 & 38 \\
\hline $\mathbf{V I}_{\mathrm{a}}$ & 78.2 & -5.8 & 91.4 & 431 & 44 \\
\hline $\mathbf{V} \mathbf{I}_{\mathrm{b}}$ & 71.9 & -9.1 & 93.4 & 413 & 33 \\
\hline $\mathbf{V I} \mathbf{I}_{\mathrm{c}}$ & 56.6 & -10.9 & 96.5 & 407 & 38 \\
\hline $\mathbf{V} \mathbf{I}_{\mathrm{d}}$ & 50.2 & -8.5 & 91.7 & 404 & 43 \\
\hline $\mathbf{V I}_{\mathrm{e}}$ & 30.9 & -9.5 & 97.0 & 376 & 42 \\
\hline $\mathbf{V} \mathbf{I}_{\mathrm{f}}$ & 22.9 & -6.6 & 96.7 & 374 & 40 \\
\hline Kapton & 85.0 & 0.3 & 90.0 & 443 & 38 \\
\hline
\end{tabular}

${ }^{\text {a }}$ The color parameters were calculated according to a CIE $\mathrm{LAB}$ equation, using paper as a standard. $L^{*}$ is lightness; 100 means white, while 0 implies black. A positive $a^{*}$ means red color, while a negative $a^{*}$ indicated green color. A positive $b^{*}$ means yellow color, while a negative $b^{*}$ implies blue color. ${ }^{\mathrm{b}}$ Transparency cut-off wavelength in $\mathrm{nm} .{ }^{\mathrm{c}}(\mathrm{H})$ : Polyimides were obtained by the thermal imidization method. (C): Polyimides were obtained by the chemical imidization method.

linkage between the phthalimide units, and $\mathbf{V}_{\mathrm{a}}$ derived from PMDA exhibited the highest $T_{\mathrm{g}}$ due to the rigid pyromellitimide unit.

The thermal stability of the polymers was evaluated by TGA conducted at a heating rate of $20^{\circ} \mathrm{C} / \mathrm{min}$. The temperatures of $10 \%$ weight loss $\left(T_{10}\right)$ in nitrogen and air atmospheres were determined from original TGA thermograms and are also tabulated in Table V. The $T_{10}$ values of $\mathbf{V}_{\mathrm{a}-\mathrm{f}}$ stayed within $512-543^{\circ} \mathrm{C}$ in nitrogen and within $518-538^{\circ} \mathrm{C}$ in air. They left more than a $54 \%$ char yield at $800{ }^{\circ} \mathrm{C}$ in nitrogen. BPDA-derived $\mathbf{V}_{\mathrm{c}}$ had the highest $T_{10}$ and char yield. $\mathbf{V}_{\mathrm{d}}$ having a sulfonyl group in dianhydride DSDA exhibited lower $T_{10}$ values than the other polyimides. This might be attributed to the weak bonding of $\mathrm{C}-\mathrm{S}$ bond and easily degradation on the heating process. $\mathbf{V \mathbf { I } _ { \mathrm { d } }}$ also showed lower thermal stability. Figure 8 shows typical TG curves for the representative $\mathbf{V}_{\mathrm{c}, \mathrm{d}}$ and $\mathbf{V} \mathbf{I}_{\mathrm{c}, \mathrm{d}}$ in nitrogen and air atmospheres. The curves of series $\mathbf{V}$ in nitrogen showed higher thermal stability than series VI did. 


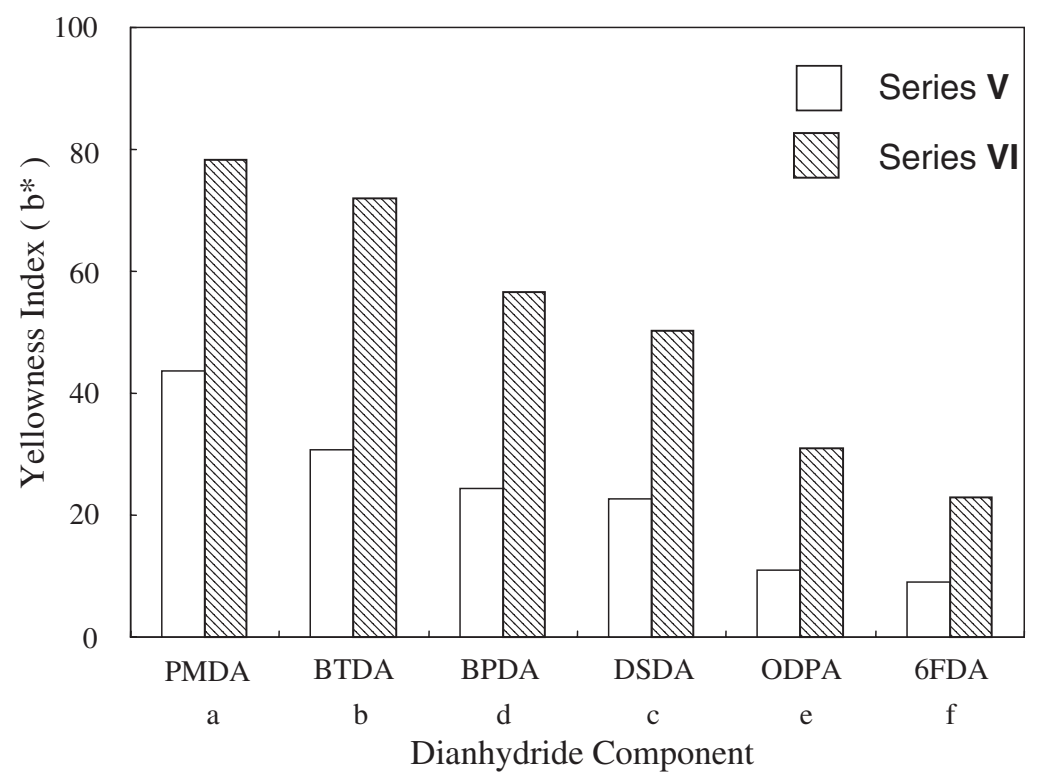

Figure 6. Comparison of the yellowness index ( $b^{*}$ value) between polyimide $\mathbf{V}$ and VI.

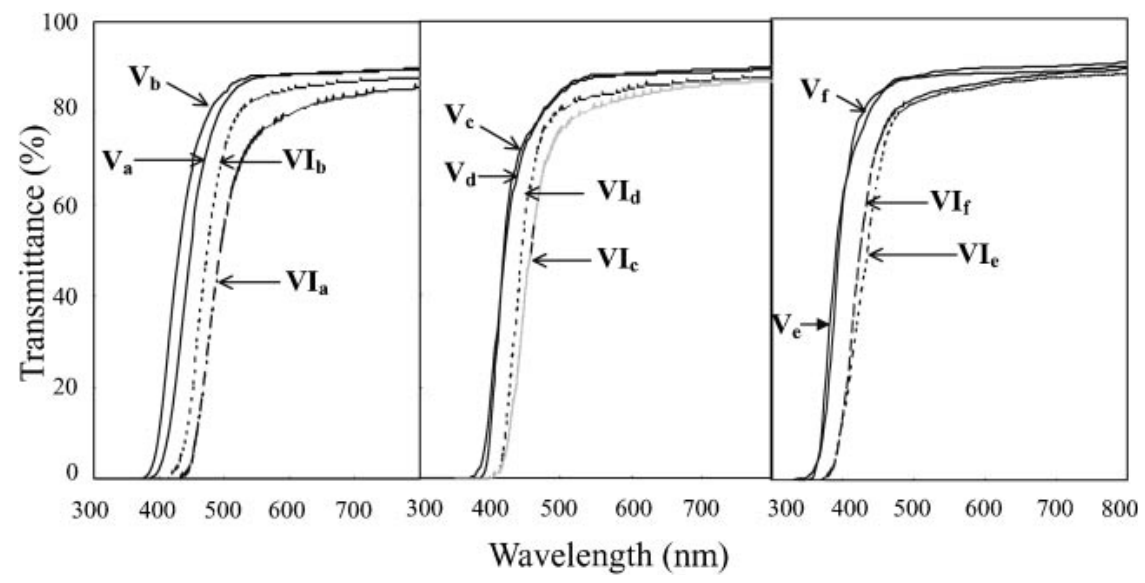

Figure 7. UV-vis spectra of polyimide films.

Table IV. Tensile properties of polyimide films

\begin{tabular}{cccc}
\hline Polymer $^{\mathrm{a}}$ & $\begin{array}{c}\text { Strength } \\
\text { at break } \\
(\mathrm{MPa})\end{array}$ & $\begin{array}{c}\text { Elongation } \\
\text { at break } \\
(\%)\end{array}$ & $\begin{array}{c}\text { Initial } \\
\text { modulus } \\
(\mathrm{GPa})\end{array}$ \\
\hline $\mathbf{V}_{\mathrm{a}}$ & 120 & 10 & 2.55 \\
$\mathbf{V}_{\mathrm{b}}$ & 125 & 12 & 2.65 \\
$\mathbf{V}_{\mathrm{c}}$ & 122 & 11 & 2.42 \\
$\mathbf{V}_{\mathrm{d}}$ & 105 & 9 & 2.35 \\
$\mathbf{V}_{\mathrm{e}}$ & 112 & 11 & 2.37 \\
$\mathbf{V}_{\mathrm{f}}$ & 110 & 10 & 2.36 \\
\hline
\end{tabular}

${ }^{\text {a}}$ Polyimides were obtained by the thermal imidization method.

In the air, series $\mathbf{V}$ had less weight loss below $620^{\circ} \mathrm{C}$, but the decomposition rate of series VI became lower at higher temperature.

The measurements of the dielectric constants were performed between gold layers: the polymer film was dried carefully, and a thin gold layer was vacu-
Table V. Thermal properties of polyimides

\begin{tabular}{|c|c|c|c|c|}
\hline \multirow{3}{*}{ Polymer $^{\mathrm{a}}$} & \multirow{2}{*}{ DSC } & \multicolumn{3}{|c|}{ TGA } \\
\hline & & \multicolumn{2}{|c|}{ Decomposition temp ${ }^{\mathrm{c}}\left({ }^{\circ} \mathrm{C}\right)$} & \multirow{2}{*}{$\begin{array}{c}\text { Char yield } \\
\text { (wt \%) }\end{array}$} \\
\hline & $T_{\mathrm{g}}^{\mathrm{b}}\left({ }^{\circ} \mathrm{C}\right)$ & In air & In nitrogen & \\
\hline $\mathbf{V}_{\mathrm{a}}$ & 320 & 531 & 532 & 54 \\
\hline $\mathbf{V}_{\mathrm{b}}$ & 273 & 535 & 540 & 56 \\
\hline $\mathbf{V}_{\mathrm{c}}$ & 289 & 538 & 543 & 60 \\
\hline $\mathbf{V}_{\mathrm{d}}$ & 282 & 518 & 512 & 55 \\
\hline $\mathbf{V}_{\mathrm{e}}$ & 259 & 536 & 540 & 58 \\
\hline $\mathbf{V}_{\mathrm{f}}$ & 278 & 535 & 538 & 55 \\
\hline
\end{tabular}

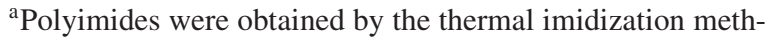
od. ${ }^{b}$ Midpoint of baseline shift in the second heating DSC trace with a heating rate of $15^{\circ} \mathrm{C} / \mathrm{min}$ under a nitrogen atmosphere. ${ }^{\mathrm{c}}$ Temperatures at which $10 \%$ weight loss were recorded by TG at a heating rate of $20{ }^{\circ} \mathrm{C} / \mathrm{min} .{ }^{\mathrm{d}}$ Residual wt $\%$ at $800{ }^{\circ} \mathrm{C}$ under a nitrogen atmosphere. 


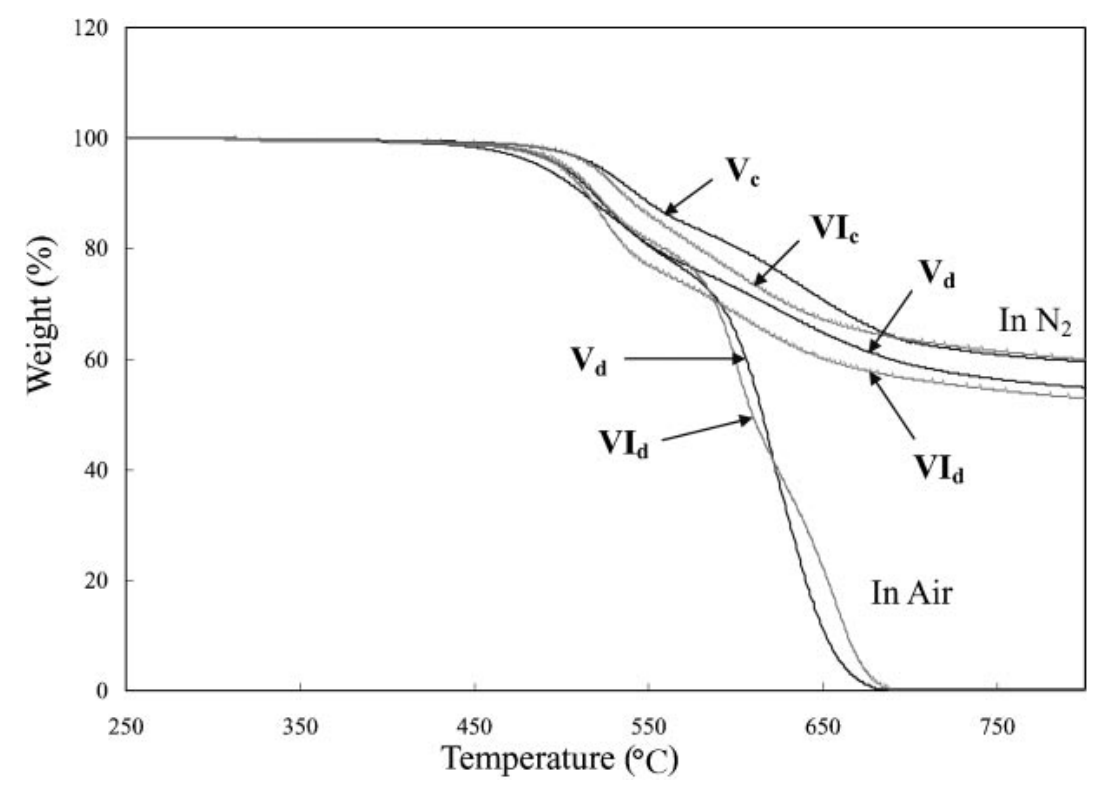

Figure 8. Typical TGA curves of polyimides $\mathbf{V}_{\mathrm{c}, \mathrm{d}}$ and $\mathbf{V \mathbf { I } _ { \mathrm { c } , \mathrm { d } }}$ with a heating rate of $20^{\circ} \mathrm{C} / \mathrm{min}$.

Table VI. Moisture absorption and dielectric constants of polyimides

\begin{tabular}{|c|c|c|c|c|c|c|}
\hline \multirow{2}{*}{ Polymer $^{\mathrm{a}}$} & \multirow{2}{*}{$\begin{array}{c}\text { Film } \\
\text { thickness } \\
(\mu \mathrm{m})\end{array}$} & \multirow{2}{*}{$\begin{array}{c}\text { Moisture } \\
\text { absorption } \\
(\%)\end{array}$} & \multicolumn{4}{|c|}{ Dielectric constant ${ }^{\mathrm{b}}$} \\
\hline & & & $1 \mathrm{kHz}$ & $10 \mathrm{kHz}$ & $1 \mathrm{MHz}$ & $40 \mathrm{MHz}$ \\
\hline $\mathbf{V}_{\mathrm{a}}$ & 31 & 0.24 & 3.18 & 3.16 & 3.11 & 3.08 \\
\hline $\mathbf{V}_{\mathrm{b}}$ & 30 & 0.26 & 3.17 & 3.15 & 3.07 & 3.09 \\
\hline $\mathbf{V}_{\mathrm{c}}$ & 33 & 0.22 & 3.11 & 3.05 & 2.98 & 2.95 \\
\hline $\mathbf{V}_{\mathrm{d}}$ & 32 & 0.27 & 3.07 & 3.03 & 2.96 & 2.93 \\
\hline $\mathbf{V}_{\mathrm{e}}$ & 34 & 18 & 2.91 & 2.85 & 2.82 & 2.79 \\
\hline $\mathbf{V}_{\mathrm{f}}$ & 32 & 0.12 & 2.77 & 2.73 & 2.70 & 2.72 \\
\hline $\mathbf{V I}_{\mathrm{a}}$ & 35 & 0.32 & 3.59 & 3.52 & 3.43 & 3.40 \\
\hline $\mathbf{V} \mathbf{I}_{\mathrm{b}}$ & 33 & 0.37 & 3.40 & 3.38 & 3.26 & 3.29 \\
\hline $\mathbf{V I}_{\mathrm{c}}$ & 34 & 0.31 & 3.41 & 3.36 & 3.28 & 3.22 \\
\hline $\mathbf{V} \mathbf{I}_{\mathrm{d}}$ & 37 & 0.34 & 3.39 & 3.35 & 3.22 & 3.18 \\
\hline $\mathbf{V} \mathbf{I}_{\mathrm{e}}$ & 33 & 0.26 & 3.19 & 3.16 & 3.11 & 3.07 \\
\hline $\mathbf{V I} \mathbf{I}_{\mathrm{f}}$ & 30 & 0.21 & 3.07 & 3.03 & 2.98 & 2.94 \\
\hline Kapton $^{c}$ & 40 & 0.42 & 3.89 & 3.85 & 3.80 & 3.75 \\
\hline
\end{tabular}

aPolyimides were obtained by the thermal imidization method. ${ }^{b}$ Measured by DEA at room temperature (dry dielectric constant). ${ }^{\mathrm{c}} \mathrm{A}$ reference polyimide prepared from PMDA and $4,4^{\prime}$-oxydianiline $\left(\eta_{\text {inh }}\right.$ of the poly(amic acid) precursor $1.90 \mathrm{dL} / \mathrm{g})$.

um-deposited on both surfaces of the film. This procedure excluded any contact problems. Table VI shows the results. Fluorinated polyimides $\mathbf{V}_{\mathrm{a}-\mathrm{f}}$ had lower dielectric constants (2.70-3.11 at $1 \mathrm{MHz})$ than commercial polyimides such as Kapton films $(3.8$ at $1 \mathrm{MHz})$ and nonfluorinated polyimides $\mathbf{V I}_{\mathrm{a}-\mathrm{f}}(2.98-3.43$ at $1 \mathrm{MHz}$ ). The decreased dielectric constants might be attributable to the presence of bulky $\mathrm{CF}_{3}$ groups, which resulted the strong electronegativity of fluorine leading to very low polarizability of the $\mathrm{C}-\mathrm{F}$ bonds, thereby decreasing the dielectric constant. Hence, the 6FDA-derived $\mathbf{V}_{\mathrm{f}}$ exhibited the lowest dielectric constant than those of $\mathbf{V}_{\mathrm{a}-\mathrm{e}}$ prepared from the other dianhydrides $\left(\mathbf{I I I}_{\mathrm{a}-\mathrm{e}}\right)$. Table VI also presents the moisture absorption of the polyimides. $\mathbf{V}_{\mathrm{a}-\mathrm{f}}$ exhibited lower moisture absorptions $(0.12-0.27 \%)$ than the corresponding nonfluorinated homologues $\mathbf{V I}_{\mathrm{a}-\mathrm{f}}$ $(0.21-0.37 \%)$ and Kapton film $(0.42 \%)$ did, owing to the hydrophobicity of $\mathrm{CF}_{3}$ group. Moreover, $\mathbf{V}_{\mathrm{f}}$ and $\mathbf{V} \mathbf{I}_{\mathrm{f}}$ exhibited the lowest moisture absorption in two series due to the higher fluorine content in the repeating unit.

\section{CONCLUSIONS}

A high-purity, white fluorinated diamine, 3,3-bis[4(4-amino-2-trifluoromethylphenoxy)phenyl]phthalide (II), was prepared through nucleophilic substitution reaction of phenolphthalein and 2-chloro-5-nitrobenzotrifluoride, followed by catalytic reduction with hydrazine. A series of light-colored and organosoluble polyimides $\mathbf{V}$ have been obtained from II with different aromatic dianhydrides. These polymers were characterized by excellent thermal stability and good mechanical property. They exhibit better solubility, lighter color, lower dielectric constant, and lower moisture absorption than corresponding nonfluorinated polyimides.

Acknowledgment. The authors are grateful to the National Science Council of the Republic of China for the support of this work (Grant NSC 92-2216-E036-004). 


\section{REFERENCES}

1. C. Feger, M. M. Khojasteh, and M. S. Htoo, Ed., “Advances in Polyimide Science and Technology," Technomic Publishing, Lancaster, PA, 1993.

2. M. J. M. Adadie and B. Sillion, Ed., "Polyimides and other High-Temperature Polymers," Elsevier Biomedical, Amsterdam, 1991.

3. K. L. Mittal, Ed., "Polyimide: Synthesis, Characterization, and Application," Vol. I\&II, Plemnum, New York, N.Y., 1984.

4. C. Feger, M. M. Khojasteh, and J. E. McGrath, Ed., "Polyimides, Chemistry and Characterization," Elsevier Biomedical, Amsterdam, 1989.

5. P. E. Cassidy, "Thermally Stable Polymers," Marcel Dekker, New York, N.Y., 1980.

6. H. H. Yang, "Aromatic High-Strength Fibers," Wiley, New York, N.Y., 1989.

7. a) B. S. Dupont and N. Bilow, U.S. Patent, 4,592,925 (1986) b) A. L. Landis and A. B. Naselow, U.S. Patent, 4,645,824 (1987).
8. a) K. Higashi and Y. Noda, Eur. Patent, 240249 (1986) b) S. Tamai, M. Ohta, S. Kawashima, H. Oikawa, K. Ohkoshi, and A. Yamaguchi, Eur. Patent, 234882 (1987).

9. T. Matsuura, S. Ando, S. Sasaki, and F. Yamamoto, Electron. Lett., 29, 2107 (1993).

10. S. Ando, T. Sawada, and Y. Inoue, Electron. Lett., 29, 2143 (1993).

11. D. Wilson, H. D. Stenzenberger, and P. M. Hergenrother, Ed., "Polyimides," Black \& Son, Glasgow, U.K., 1990.

12. M. K. Ghosh and K. L. Mittal, Ed., "Polyimides: Fundamentals and Applications," Marcel Dekker, New York, N.Y., 1996.

13. F. Li, S. Fang, J. J. Ge, P. S. Honigfort, J. C. Chen, F. W. Harris, and S. Z. D. Cheng, Polymer, 40, 4571 (1999).

14. F. Li, J. J. Ge, P. S. Honigfort, S. Fang, J. C. Chen, F. W. Harris, and S. Z. D. Cheng, Polymer, 40, 4987 (1999).

15. C. S. Wang and R. W. Yang, J. Appl. Polym. Sci., 66, 609 (1997).

16. C. P. Yang and J. H. Lin, J Polym. Sci., Part A: Polym. Chem., 32, 369 (1994).

17. C. P. Yang and J. H. Lin, J Polym. Sci., Part A: Polym. Chem., 32, 423 (1994). 